\title{
K osvojení dítěte registrovanými partnery
}

\section{Adoption of a Child by Registered Partner}

\author{
Vojtěch Pospíšil*
}

\begin{abstract}
Abstrakt
Clánek se zabývá problematikou osvojeni dètí registrovanými partnery z.pobledu práva na rovné zacházení. Problematiku osvojení registrovanými partnery lęe rozlisit do trü kategorii, a to individuální nebo společné osvojeni cizího dítète a prì osvojeni dítète partner či partnerky. Pozornost je vènována visem tèmto situacím. Clánek se zabývá také nedávným nálezem Ústavního soudu, kterým byl zurušen \13 odst. 2 zákona o registrovaném partnerství, keterý registrovaným partnerüm znemožnoval osvojit ditě. V̌̉bledem k. tomu, že tato otázka se netýká pouze České republiky, čtenár bude ve stručnosti seznámen také s evropskými kontexty otárky osvojeni dètí registrovanými partnery.
\end{abstract}

\section{Klíčová slova}

Právo na rovné zacházení; osvojeni; registrované partnerství.

\begin{abstract}
The article deals with the adoption of children by civil partners from the perspective of the right to equal treatment. Adoption of children by civil partners can be divided into three categories; namely individual or joint adoption of a foreign child and the adoption of the child of second partner (second-parent adoption). Attention is paid to all these situations. The article also pays attention to the recent Constitutional Court judgment which derogated Sec. 13 para. 2 of the Act on registered partnerships that banned civil partners to adopt a child. The issue of adoption does not affect only the Caech Republic therefore the reader will be briefly acquainted with European context.
\end{abstract}

\section{Keywords}

Right to Equal Treatment; Adoption; Civil Partnership.

V nedávné době se ve veřejné i odborné debatě opět objevila otázka zákazu osvojení dítěte registrovanými partnery. ${ }^{1}$ Větší veřejnou reakci vyvolala zpráva o šetření veřejné

\footnotetext{
* Mgr. Vojtěch Pospíšil, doktorand, Právnická fakulta, Masarykova univerzita, Brno / Ph.D. student, Faculty of Law, Masaryk University, Brno, Czech Republic / Email: 348355@mail.muni.cz

1 Z odborné debaty zmiňme několik aktuálních článků, které plédují pro opačné závěry.

- BUREŠOVÁ, Kateřina. Stejnopohlavní pár v nejlepším zájmu dítěte. Prární roz̧bledy. C. H. Beck, 2016, č. 9, s. 311. ISSN 1210-6410.

- BUREŠOVÁ, Kateřina. Právní aspekty homoparentální rodiny. Rekodifikace \& praxe. Wolters Kluwer, 2015, č. 9, s. 8. ISSN 1805-6822.

- KAVALÍR, Jakub. Má smysl podpořit možnost adopce homosexuálními páry? (1.). Právo a rodina. Wolters Kluwer, 2015, č. 7, s. 20. ISSN 1212-866X

- KAVALÍR, Jakub. Má smysl podpořit možnost adopce homosexuálními páry? (2.). Právo a rodina. Wolters Kluwer, 2015, č. 8, s. 23. ISSN 1212-866X
} 
ochránkyně práv, ve které konstatovala, že tento zákaz považuje za neústavní. ${ }^{2}$ Městský soud v Praze vyhověl návrhu žalobce podpořeného závěry ochránkyně a související prrípad předložil Ústavnímu soudu. Ten zákaz osvojení registrovanými partnery jako neústavní zrušil. ${ }^{3}$ Cílem tohoto článku je přiblížit problematiku osvojení registrovanými partnery z pohledu práva na rovné zacházení.

Člověk je tvorem společenským a za svůj život vystupuje v rozličných sociálních rolích. Vstupuje a zase vystupuje do nepřeberného množství mezilidských vztahů a stává se součástí mnoha společenství a skupin. Primární skupinou, do níž člověk vstupuje prakticky ihned po narození, je jeho rodina. Rodina může mít různé podoby. Patrně nejrozšruřenější pojetí za rodinu považuje dítě a jeho biologické rodiče, tj. otce a matku. Takový pohled je ale značně zjednodušený. Rodinu dítěte čím dál častěji tvoří pouze jeden rodič. Mưže ji představovat také instituce, která o dítě namísto rodičů pečuje, at' už proto, že o něj rodiče nemají zájem pečovat, nebo toho nejsou schopni např́iklad pro zdravotní stav dítěte. V neposlední řadě mohou nejužší rodinu dítěte tvořit sociální rodiče, tj. lidé, kteří jej vychovávají, avšak nejsou jeho biologickými rodiči. Může se jednat o příbuzné pečující o sirotky, nebo i zcela nepř́buzné osoby, které osvojily rodiči nechtěné dítě, či třetí osoby pečující o dítě z jiného právního titulu, např́íklad pěstouny.

Pro větší názornost považuji za vhodné demonstrovat výše uvedená tvrzení na statistických údajích. V roce 2002 bylo v České republice 4.053.811 domácností. Z toho 49,7\% domácností bylo tvořeno rodiči a jejich dětmi. Dalších 13,2\% domácností bylo tvořeno rodiči, dětmi a dalším př́buzným. To znamená, že 62,9\% domácností tvořily rodiny $\mathrm{s}$ dětmi. Zbytek domácností byl tvořen jinými sociálními skupinami. Neúplné rodiny tvořily 5,6\% domácností a $6,7 \%$ tvořily neúplné rodiny s dalším příbuzným, tzn. v 12,3\% domácností nežil druhý rodič. Jednočlenné domácnosti byly zastoupeny ve 24,1\% a zbylých $0,8 \%$ tvořily nerodinné domácnosti, tzn. společenství vzniklá na jiném základě, než citovém či příbuzenském. ${ }^{4}$ Převažujícím modelem soužití skutečně byla rodina tvořená dvěma rodiči a jejich dětmi. Takové uspořádání však bylo zastoupeno v necelých dvou třetinách domácností a více než třetina domácnosti byla tvořena jinými společenstvími. Co se týče podílu dětí vyrůstajících v náhradních modelech rodiny, je tento poměr mnohem př́znivější. Ze 2.097.020 dětí, ${ }^{5}$ které žily v České republice v roce 2011 jich vyrůstalo v institucionální péči 9.248, z toho jich bylo 7.820 starších tří let. O dalších 10.203 dětî pečovali pěstouni a poručníci a 4.773 dětí bylo svěřeno do výchovy jiné osobě, než rodiči z důvodu nedostatečného plnění rodičovské zodpovědnosti. Celkem tedy vyrůstalo

2 Zpráva o šetření veřejné ochránkyně práv ze dne 1. července 2014, sp. zn. 2977/2014/VOP. Dostupné z: http://eso.ochrance.cz/Nalezene/Edit/880

3 Nález Ústavního soudu ze dne 14. června 2016, sp. zn. Pl. ÚS 7/15.

4 Uvedená data vychází ze statistiky Českého statistického úřadu. Dostupná z: https://www.czso.cz/documents/10180/20556821/0205.pdf/187a3af0-a353-42b1-a634-39ca7179fd96?version=1.0

5 Zde osob do 19 let věku. 
24.224 dětí mimo svou biologickou rodinu, což je přibližně $1,5 \%$ dětí. ${ }^{6} \mathrm{~K}$ tomu je třeba připočíst osvojené děti; těch přibude ročně asi $550 .^{7}$

Model soužití rodičů s dětmi je zdaleka nejčastější, avšak není modelem jediným. Uvedená statistika navíc nerozlišuje v př́padě oněch 62,9\% domácností, jaký poměr mají „rodiče“ $\mathrm{k}$ vychovávanému dítěti. V tomto podílu jsou totiž zahrnuty také osvojené děti a děti vychovávané na základě jiného právního důvodu, než rodičovství. Mezi těmito domácnostmi je jich také několik, v nichž roli rodičů sehrávají lidé stejného pohlaví. V takových domácnostech v současnosti vyrůstá nejméně 900 dětí. Problematika méně častých forem výchovy dětí se tak může zdát poměrně okrajovou, když děti ve všech těchto formách dohromady netvoří zdaleka ani $10 \%$ všech dětí v České republice. Přesto se jedná o problém palčivý, protože jeho řešení zásadním způsobem ovlivňuje současný i budoucí život těchto dětí. Navíc nahradíme-li statistické podíly absolutními čísly, dospějeme k závěru, že jsou zde desítky tisíc dětí, které nežijí ve většinou sdílené představě rodiny.

V tomto článku se zaměříme pouze na problematiku výchovy dětí stejnopohlavními páry, nebot' tato otázka se od těch ostatních odlišuje. V př́ipadě institucionální či náhradní výchovy stát vytváří nástroje, jimiž se snaží zajistit péči o děti, o které z rozličných důvodů nepečují jejich rodiče. Naopak v případě zákazu osvojení dítěte registrovanými partnery, stát omezuje možnost vzniku právního pouta osoby, která se podílí na péči o dítě.

\section{Zákaz osvojení pohledem Listiny základních práv a svobod}

Počátkem roku 2014 vstoupil v účinnost dlouho očekávaný nový občanský zákoník, ${ }^{9}$ který nahradil civilní kodex z roku $1964 .^{10}$ Přestože nový občanský zákoník zrušil přibližně dvě stě do té doby účinných předpisů a nově obsahuje mnohá ustanovení, která byla dřive obsažena v samostatných předpisech, zákon č. 115/2006 Sb., o registrovaném partnerství a o změně některých souvisejících zákonů, ve znění pozdějších předpisů (dále

6 Údaje byly čerpány ze statistik Českého statistického úřadu; Ministerstva školství, mládeže a tělovýchovy; Ministerstva práce a sociálních věcí. Dostupné z:

- http://ciselnik.artega.cz/vekova_struktura_obyvatel_cr.php

- http://www.msmt.cz/vzdelavani/socialni-programy/statistika-poctu-deti-umistenych-v-zarizenich-ochranne-a

- http://www.nahradnirodina.cz/statistiky_nahradni_vychovy_v_cr

7 Průměrný počet osvojených dětí vychází z údajů o osvojení za předchozí léta. Viz http://www.nadacetm. cz/files/files/dokumenty/Problematika_Pocty_osvojenych_deti.pdf

8 Partnerské svazky osob stejného poblaví v Ceské republice a v Evopé [online] Český statistický úřad, 24. 10. 2013 [cit. 29. 1. 2016] Dostupné z: https://www.czso.cz/documents/10180/20533820/csav102413opr. pdf/952872bd-1745-4ce0-a21b-c30bbc03ef47?version=1.0

9 Zákon č. 89/2012 Sb., občanský zákoník (dále jen „občanský zákoník“).

10 Zákon č. 40/1964 Sb., občanský zákoník, ve znění pozdějších předpisů. 
jen „zákon o registrovaném partnerstvi“), je stále účinný. Ačkoliv se jedná o normu, která institucionalizuje ty nejosobnější vztahy, nebyla do občanského zákoníku vtělena. Toto „vyloučení“ z nového komplexního kodexu je o to výraznější, že součástí občanského zákoníku se stala také problematika rodinného práva, tedy zejména manželských a příbuzenských vztahů. Nevtělení institutu registrovaného partnerství do nového občanského zákoníku lze vnímat jako odklon od současného mezinárodního diskursu, v jehož rámci jsou v poslední době posilována práva gayů a leseb. Registrované partnerství, či jiná institucionalizovaná forma soužití, se dokonce stala evropským standardem. Evropský soud pro lidská práva (dále jen „ESLP`) v rozsudku ze dne 21. října 2015, č. stížnosti 18766/11 a 36030/11, Oliari a ostatní v. Itálie, dospěl k závěru, že Itálie porušuje čl. 8 Úmluvy o ochraně lidských práv a základních svobod deklarované právo na respekt k rodinnému a soukromému životu, když neumožňuje homosexuálním párům, aby svůj vztah institucionalizovali a aby mu byla poskytnuta právní ochrana. ESLP ovšem uvedl, že touto institucionalizací nemusí být nutně manželství; může se jednat i o jiný vztah. Byt' se jedná toliko o odlišnou legislativní techniku nemající většího praktického významu, zákonodárce tímto krokem, tj. nezačleněním registrovaného partnerství do občanského zákoníku, dává najevo svou názorovou orientaci a předznamenává svůj postoj ke zrovnoprávnění stejnopohlavních párů s heterosexuálními dvojicemi.

Osvojení dítěte registrovanými partnery bylo vyloučeno ustanovením \13 odst. 2 zákona o registrovaném partnerství, které tuto možnost výslovně zakazovalo. ${ }^{11}$ Toto ustanovení znemožňovalo partnerům individuálně osvojit cizí dítě. Zákaz individuálního osvojení však Ústavní soud pro rozpor s ústavním pořádkem zrušil. ${ }^{12}$ Společné osvojení cizího dítěte je však nadále vyhrazeno manželům. ${ }^{13}$ Vedle individuálního a společného osvojení cizího dítěte lze rozlišit ještě tzv. přiosvojení dítěte jednoho z partnerů či partnerek. Těmto situací se budeme jednotlivě věnovat v následujícím textu.

Výchozím rámcem pro další zkoumání nám bude s ohledem na zaměření článku právo na rovné zacházení. Rovnost lidí je jednou ze základních hodnot demokratických právních států. Rovnost úzce souvisí s konceptem ochrany lidské důstojnosti, nebot' důstojnost člověka je chráněna pouze tehdy, je-li stejnou měrou chráněna důstojnost všech lidí. Nelze chránit důstojnost člověka, aniž by s ním nebylo zacházeno jako s rovným, tj. se stejnou pozorností a úctou, jako s ostatními lidmi. Toto poznání vychází z idey Immanuela Kanta, který považuje lidi za členy království účelů, tj. bytosti, které jsou samy o sobě a pro sebe jsoucím účelem. ${ }^{14}$ Debata o rozsahu lidských práv je vlastně otázkou,

11 Srov. „Trvajici partnerství bráni tomu, aby se některý zpartnerů stal osvojïtelem dítéte. \13 odst. 2 zákona o registrovaném partnerství.

12 Stalo se tak nálezem Ústavního soudu ze dne 14. června 2016, sp. zn. Pl. ÚS 7/15. Rozboru tohoto nálezu se budeme věnovat níže v samostatné části.

13 Ustanovení \ 800 odst. 1 občanského zákoníku.

14 Blíže KANT, Immanuel. Kritike praktického rozumu. 1. vydání. Praha: Svoboda, 1996, s. 225. 
do jaké míry by měl stát respektovat jedinečnost každé osoby a na základě kterých znaků může naopak mezi lidmi rozlišovat. ${ }^{15}$

Rovnost je deklarována ustanovením čl. 1 a čl. 3 odst. 1 Listiny základních práv a svobod (dále jen „Listina ${ }^{6}$ ). ${ }^{16}$ Ústavní soud tato ustanovení vykládá jako neakcesorickou a akcesorickou rovnost. V prvém prrípadě je rovnost hodna ochrany sama o sobě, ${ }^{17} \mathrm{za}-$ tímco ve druhém přistupuje až jako kritérium př́stupu k ostatním základním právům. Tento prístup je doktrínou oprávněně kritizován, nebot’ nesleduje účel deklarovaného práva na rovné zacházení, tj. chránit důstojnost člověka. Namísto toho přejímá koncept vytvořený ESLP na půdorysu Úmluvy o ochraně lidských práv a svobod, která má však pro toto dělení výraznější dispozici. ${ }^{18}$ Od tohoto dichotomického pojetí se odvíjí také dvojí poměřování souladu předmětné úpravy s rovností ve smyslu čl. 1 Listiny a rovností, respektive zákazem diskriminace, ve smyslu čl. 3 odst. 1 Listiny.

Princip rovnosti (čl. 1 Listiny) považuje Ústavní soud za zákaz rozlišování mezi srovnatelnými osobami, aniž by pro rozdílné zacházení existovaly objektivní a rozumné důvody. ${ }^{19}$ Porušení tohoto zákazu by znamenalo nepř́pustnou libovưli zákonodárce. Ústavní soud k tomu ve svých nálezech opakovaně uvádí: „Je věcí státu, aby v zájmu zabezpečení svých funkci roz̧hodl, že určité skupině poskytne méně výhod než̃öné. Ani żde však nesmi postupovat żcela libovolnè... Pokud zákon určuje prospèch jedné skupiny a zároveñ tím stanoví neúmèrné povinnosti jiné, mưže se tak stát pouze s odvoláním na veřejné hodnoty". ${ }^{20}$ Zákonodárce nemůže rozlišovat mezi lidmi bez objektivních a rozumných důvodů. Slovy amerického právního filosofa, Ronalda Mylese Dworkina, stát musí zacházet s těmi, jimž vládne, se stejnou pozorností a úctou. ${ }^{21}$ Tento požadavek se projevuje jako ,právo na rovný díl statkư nebo príležitostí, jaký má každý jiný nebo jaký se poskytuje každému jinému“" a dále jako povinnost stejné (rovné) pozornosti a úcty k zájmům všech lidí při rozhodování o distribuci dober. ${ }^{22}$ Jinými

15 Srov. nález Ústavního soudu ze dne 7. prosince 2005, sp. zn. IV. ÚS 412/04, část IV., nebo nález Ústavního soudu ze dne 29. února 2008, sp. zn. II. ÚS 2268/07, bod 43.-45.

16 Usnesení předsednictva České národní rady č. 2/1993 Sb., o vyhlášení Listiny základních práv a svobod jako součásti ústavního pořádku České republiky.

17 „[]eví se proto Ústavnimu soudu jako neadekvátni tendence vtèsnat každé úsili o dosažení rovnosti do rámce etablování zákeladnich lidských práv, ježsvou povahou prérnivaji nad „politiku každodennosti“. To proto také znamená, že nerovnost v sociálnich vątazích, má-li se dotknout základnich lidských práv, musi dosábnout intenzity, zpochybrujuicí, alespoň v určitém smèru, již samu podstatu rovnosti. Tak se zpravidla dèje tebdy, je-li s porušením rovnosti spojeno i porušeni jinébo základního práva". Nález Ústavního soudu ze dne 7. června 1995, sp. zn. Pl. ÚS 4/95.

18 Blíže WAGNEROVÁ, E., ŠIMÍČEK, V., LANGÁŠEK, T., POSPÍŠIL, I. a kol. Listina quákladních práv a svobod. Komentár. Praha: Wolters Kluwer ČR, 2012, s. 99.

19 Nález Ústavního soudu ze dne 16. října 2007, sp. zn. Pl. ÚS 53/04.

20 Nález Ústavního soudu ČSFR, sp. zn. Pl. ÚS 22/92, ze dne 8. října 1992. I když se jedná o nález federálního Ústavního soudu, Ústavní soud ČR na něj opakovaně odkázal. Naposled ve svém nálezu ze dne 26. května 2009, sp. zn. Pl. ÚS 40/08.

21 Viz DWORKIN, Ronald Myles. Když se práva berou vážně. Praha: OIKOYMENH, 2001, s. 336.

22 Tamtéž, s. 337. 
slovy, zákonodárce není povinen zrovnoprávnit registrované partnerství a manželství, ale $\mathrm{v}$ případě, že hodlá poskytnout registrovaným partnerům méně výhod, musí takové rozlišení racionálně zdůvodnit. Za ústavně konformní lze proto považovat pouze takové rozlišování, které sleduje objektivní a rozumný důvod a přijaté opatření je tomuto cíli přiměřené. ${ }^{23} \mathrm{~V}$ následující části se proto budeme věnovat racionalitě zákazu osvojení dítěte registrovanými partnery.

Důvodová zpráva k zákonu o registrovaném partnerství uvádí, že osvojení dítěte registrovanými partnery je zakázáno z důvodu ,preference nábradni výchovy dítéte heterosexuálním párem“. Není však blíže zdo̊vodněno, proč je preferována náhradní péče heterosexuálními páry. Předpokládáme proto, že zákonodárce považoval sexuální orientaci vychovatelů za podstatný faktor kvality rodičovské péče. Tato domněnka však byla opakovaně vyvrácena kvalitativními i kvantitativními psychologickými výzkumy. ${ }^{24}$

Tradičně bývá namítáno, že děti vychovávané stejnopohlavními páry jsou ve zvýšené míre vystaveny šikaně a posměchu okolí, zejména ostatních dětí v mateřské a základní škole. Tento předpoklad ale byl v českém prostředí vyvrácen empirickým pozorováním. Ukázalo se, že tato odlišnost je jen jednou z celé řady, které mezi dětmi jsou a s nimiž se musí vyrovnat. ${ }^{25}$ Nebylo ani prokázáno, že by se děti vyrůstající ve stejnopohlavní rodině výrazněji lišily od dětí vychovávaných heterosexuálním párem. Naopak tyto děti bývají otevřenější a tolerantnějšíi ${ }^{26}$ Proti stejnopohlavnímu rodičovství bývá také namítáno, že těmto dětem chybí vzor druhého pohlaví. Pokud bychom přítomnost vzoru chování obou pohlaví považovali za natolik významnou pro zdárný vývoj dítěte, mělo by být

23 Srov. nález ústavního soudu ze dne 16. ř́jna 2007, sp. zn. Pl. ÚS 53/04.

24 Např. PAZLAROVÁ, Hana. Rodiče stejného pohlaví? - př́íspěvek do diskuse. In: Fórum sociální práce. Praha: Univerzita Karlova, 2010, č. 1, s. 97-100. ISSN 1804-3070.

- BRAUN, Richard. Modely gay a lesbických rodin. In: Fórum sociální práce. Praha: Univerzita Karlova, 2010, č. 1, s. 109-111. ISSN 1804-3070.

- AVERETT, Paige, Blace NALAVANY a Scott RYAN. An Evaluation of Gay/Lesbian and Heterosexual Adoption. Adoption Quarterly [online]. 2009-11-30, vol. 12, 3-4, s. 129-151 [cit. 9. 1. 2016]. Dostupné z: http://www.tandfonline.com/doi/abs/10.1080/10926750903313278

- GOLOMBOK, Susan, Laura MELLISH, Sarah JENNINGS, Polly CASEY, Fiona TASKER a Michael E. LAMB. Adoptive Gay Father Families: Parent-Child Relationships and Children's Psychological Adjustment. Child Development [online]. 2014, vol. 85, issue 2, s. 456-468 [cit. 9. 1. 2016]. Dostupné z: http://doi.wiley.com/10.1111/cdev.12155

- CROUCH, Simon, Elizabeth WATERS, Ruth McNAIR, Jennifer POWER a Elise DAVIS. Parent-reported measures of child health and wellbeing in same-sex parent families: a cross-sectional survey. BMC Public Health [online]. 2014, vol. 14, issue 1, s. 635- [cit. 9. 1. 2016]. Dostupné z: http://www. biomedcentral.com/1471-2458/14/635

25 Viz PAZLAROVÁ, Hana. Rodiče stejného pohlaví? - příspěvek do diskuse. In: Fórum sociálnípráce. Praha: Univerzita Karlova, 2010, č. 1, s. 97-100. ISSN 1804-3070.

BRAUN, Richard. Modely gay a lesbických rodin. In: Fórum sociálnípráce. Praha: Univerzita Karlova, 2010, č. 1, s. 109-111. ISSN 1804-3070.

26 POLÁŠKOVÁ, Eva. Jen sexuální orientace dobrého nebo špatného rodiče nedělá. In: Fórum sociálni práce. Praha: Univerzita Karlova, 2010, č. 1, s. 105-107. ISSN 1804-3070. 
obdobně zakázáno osamělým rodičům vychovávat své děti, protože i v těchto prípadech chybí vzor druhého pohlaví. Což se jeví jako poněkud absurdní požadavek.

V zahraniční bylo provedeno několik kvantitativních a kvalitativních výzkumů, které svými výsledky potvrzují výše uvedená zjištění české praxe. Studie zaměřená na emoční a behaviorální problémy mezi osvojenými dětmi vychovávanými stejnopohlavními a různopohlavními páry ukázala, že tyto problémy jsou zastoupeny u obou skupin v zásadě stejně. ${ }^{27}$ Jiný výzkum, zaměřený na kvalitu vztahu rodičů a dětí a psychologické přizpưsobení dětí vychovávaných ženou a mužem, nebo dvěma muži, ukázal, že gay rodiče jsou ve větší psychické pohodě, více projevují náklonnost $\mathrm{k}$ dítěti a více se mu věnují. Děti v heterosexuálních rodinách byly naopak mírně častěji hyperaktivní. Jiné rozdíly však zjištěny nebyly. ${ }^{28}$ Jeden z doposud nejrozsáhlejších výzkumů se týkal asi 500 dětí, a ukázal, že děti vychovávané stejnopohlavními páry mají lepší celkový zdravotní vztah a jejich rodiny vykazují vyšší soudržnost. Ostatní sledované ukazatele byly u obou skupin srovnatelné. ${ }^{29}$

Odborné výzkumy prokázaly, že výchova dětí stejnopohlavními páry nepřináší dětem žádné znevýhodnění ani nemusí nezbytně znamenat nepřekonatelnou překážku socializace dítěte.

Jestliže prrijmeme poznatky ostatních vědních disciplín, které považují homosexuály a heterosexuály v obecné rovině za stejně způsobilé $\mathrm{k}$ výchově dětí, budeme schopni obhájit trvající nemožnost společného osvojení cizího dítěte registrovanými partnery jen obtížně. Domníváme se proto, že stejně jako byl zrušen zákaz individuálního osvojení, mělo by být partnerům umožněno také společné osvojení. Konečně samotné umožnění osvojení cizích dětí registrovanými partnery nepovede bez dalšího k jejich skutečnému osvojení, ale pouze umožní registrovaným partnerům se o osvojení ucházet. Posouzení jejich konkrétních kvalit a udělení př́padného souhlasu s osvojením by nadále zůstalo na rozhodnutí soudu, který posuzuje především zájmy dítěte. ${ }^{30}$

Poslední situací, jíž se budeme věnovat, je přiosvojení dítěte partnera. V takové situaci o dítě zpravidla fakticky pečují oba partneři žijící ve společné domácnosti s dítětem. Part-

27 AVERETT, Paige, Blace NALAVANY a Scott RYAN. An Evaluation of Gay/Lesbian and Heterosexual Adoption. Adoption Quarterly [online]. 2009-11-30, vol. 12, 3-4, s. 129-151 [cit. 9. 1. 2016]. Dostupné z: http://www.tandfonline.com/doi/abs/10.1080/10926750903313278

28 GOLOMBOK, Susan, Laura MELLISH, Sarah JENNINGS, Polly CASEY, Fiona TASKER a Michael E. LAMB. Adoptive Gay Father Families: Parent-Child Relationships and Children's Psychological Adjustment. Child Development [online]. 2014, vol. 85, issue 2, s. 456-468 [cit. 9. 1. 2016]. Dostupné z: http:// doi.wiley.com/10.1111/cdev.12155

29 CROUCH, Simon, Elizabeth WATERS, Ruth McNAIR, Jennifer POWER a Elise DAVIS. Parent-reported measures of child health and wellbeing in same-sex parent families: a cross-sectional survey. BMC Public Health [online]. 2014, vol. 14, issue 1, s. 635- [cit. 9. 1. 2016]. Dostupné z: http://www.biomedcentral.com/1471-2458/14/635

30 Viz ustanovení \ 795 a \ 796 odst. 1 občanského zákoníku. 
ner, který není rodičem dítěte, je navíc ze zákona povinen podílet se na výchově a péči o dítě. ${ }^{31}$ Právní úprava $\mathrm{v}$ tomto případě staví partnera-nerodiče do nezáviděníhodného postavení. Na jedné straně je povinen o dítě pečovat, ale na straně druhé nemá žádná práva, která by mu usnadnila výkon této povinnosti. Představit si lze překážky také při výkonu zcela běžných úkonů, jako doprovod dítěte k lékaři, či jeho vyzvedávání ze zařízení, kde je o něj pečováno (zejména mateřská škola, škola, školní družina, apod.). Dítě tak nemusí být partnerovi nemajícímu k dítěti žádný právní vztah vydáno a nemusí mu být poskytnuta ani žádná informace týkající se zdravotního stavu dítěte a tento partner ani není oprávněn poskytovat souhlas s vybraným způsobem léčby. Současná úprava navíc může znevýhodňovat samotné nezletilé dítě, které často může mít pouze jediného právního rodiče, respektive rodičku. Tím je ohroženo další setrvání dítěte ve svém rodinném prostředí v prrípadě, že jeho právní rodič není schopen se o něj dále starat. Dítě má také pouze jedinou osobu, která je povinna jej vyživovat. Znemožnění osvojení registrovanými partnery nejen nesleduje racionální důvod, ale ani nezohledňuje zájmy dotčených dětí, respektive je podřizuje blíže neodůvodněnému záměru, aby děti nebyly vychovávány stejnopohlavními páry. Domníváme se proto, že by právo mělo zohlednit současnou společenskou realitu, ve které homoparentální rodiny již existujî a do budoucna existovat budou a umožnit registrovaným partnerům přiosvojit dítě svého partnera či partnerky za stejných podmínek, jako v př́padě manželů.

\section{Zrušující nález Ústavního soudu P1. ÚS 7/15}

Dne 28. června 2016 Ústavní soud vyhlásil nález, jímž zrušil ustanovení \13 odst. 2 zákona o registrovaném partnerství, který znemožňoval registrovaným partnerům osvojit dítě. Registrovaní partneři tak napřriště mohou individuálně osvojit právně volné dítě.

Předmětný zákaz osvojení podle Ústavního soudu porušoval právo registrovaných partnerů na rovné zacházení dle čl. 1 Listiny, tj. neakcesorickou rovnost v právech a důstojnosti a také právo na zachování lidské důstojnosti dle čl. 10 odst. 1 Listiny.

Nález sice byl přijat poměrně výraznou většinou. Disentující stanovisko uplatnil pouze jediný soudce, přesto je z něj patrná pluralita názorů jednotlivých soudců pléna. To se projevuje kromě uplatnění třech konkurujících stanovisek, tj. celkem čtyř odlišných stanovisek, také v samotném odůvodnění. Než Ústavní soud přistoupil k samotnému posuzování souladu úpravy s ústavním pořádkem, opakovaně zdůraznil svou konzervativní hodnotovou orientaci a prŕḱklon $\mathrm{k}$ tradičnímu pojetí rodiny. ${ }^{32}$ Tradiční rodinu podle Ústavního soudu tvoří žena, muž a dítě. V současnosti však podle našeho názoru je ohrožen spíše samotný koncept rodiny jako soužití vzájemně si pomáhajících lidí vychovávajících děti, nežli její tradiční podoba. Ve společnosti prúbývá lidí, kteří netou-

31 Ustanovení \ 13 odst. 3 zákona o registrovaném partnerství.

32 Body 36. - 39. nálezu Ústavního soudu ze dne 14. června 2016, sp. zn. Pl. ÚS 7/15. 
ží formalizovat svůj svazek, respektive nepovažují existenci manželství za nezbytnou pro zplození dítěte. ${ }^{33}$ Nabízí se proto otázka, zda by mělo být manželství pojímáno jako společenství muže a ženy, které však v současnosti nesměřuje ve všech prrípadech k výchově dětí ${ }^{34}$ anebo jako společenství lidí, kteří chtějí spolu trvale žít se závazkem vzájemné pomoci a př́ipadné výchovy dětí. ${ }^{35}$ Ústavní soud však výrazně naznačil, že v př́ipadě posuzování ústavnosti omezení manželství pouze pro heterosexuály by žrejmě nedospěl s takovou lehkostí k závěru, že jsou homosexuálové stavěni do pozice občanů druhé kategorie, jako v př́padě zákazu osvojení. ${ }^{36}$

Nosným důvodem pro konstatování porušení práva na rovné zacházení dle čl. 1 Listiny byla zejména iracionalita úpravy. Jednotlivec nežijící v žádném právním svazku se mohl stát osvojitelem zcela bez ohledu na jeho sexuální orientaci, avšak uzavřením registrovaného partnerství tuto možnost ztrácel. Ústavní soud se touto argumentací vyhnul otázce srovnávání postavení registrovaných partnerů a manželů ve vztahu k osvojení dítěte, tedy jejich vhodností být rodiči. Takové závěry by však mohly vést $\mathrm{k}$ dalším Ústavním soudem nezamýšleným důsledkům, jako např́iklad otevření otázky manželství pro všechny nebo společného osvojení partnery či přiosvojení. Mưžeme jen spekulovat, zda tyto obavy stály také za absencí jakéhokoliv testu, jímž by bylo poměřováno porušení čl. 1 Listiny.

V následující části odůvodnění se Ústavní soud zabývá otázkou porušení práva na zachování důstojnosti. Tato část působí poněkud nekompatibilně s předchozí spíše konzervativní částí, nebot’ Ústavní soud přechází k hodnotové argumentaci a akcentuje jedinečnost každého člověka. Důsledný respekt této jedinečnosti však podle našeho názoru nevyhnutelně vede k plnému zpřístupnění osvojení a manželství také homosexuálům. Jakýmkoliv náznakům v tomto směru se však Ústavní soud v předchozí části snažil vyhnout, respektive je popřel.

33 V roce 1993 se mimo manželství narodilo necelých 13\% narozených dětí. V roce 2010 se již jednalo o více než 40\% narozených dětí. Pǒ̌et a struktura narožených [online] Český statistický úřad, 2010 [cit. 21. 8. 2016] Dostupné z: https://www.czso.cz/documents/10180/20566735/400811a1.doc/ f87cb721-0323-4b5b-b455-7533f4d4d86c?version=1.0

Vedle toho také stoupá rozvodovost manželství. Zatímco v roce bylo rozvedeno 35\% manželství, v roce 2015 to bylo po poklesech v předchozích letech 45\% manželství. Úhrnná rozvodovost v letech 19502015 [online] Český statistický úřad, 2016 [cit. 21. 8. 2016] Dostupné z: https://www.czso.cz/csu/czso/ uhrnna-rozvodovost-v-letech-1950-2015

34 V roce 2011 z necelých 2.200.000 vdaných žen bylo přes 240.000 žen bezdětných, přičemž přes 111.000 jich bylo starších 50 let tedy ve věku, kdy je plodnost žen podstatně snížena. Z 606.000 rozvedených žen bylo bezdětných 100.000 žen.

35 Na možné negativní dopady těchto hodnotových prohlášení Ústavního soudu upozornil ve svém konkurujícím stanovisku soudce Ludvík David. Podle něj by tyto pasáže mohly přispět k faktickému znevýhodnění registrovaných partnerů při rozhodování o osvojení dítěte. Soudce David také připomíná, že evropské pojetí rodiny se neomezuje pouze na vztah mezi mužem a ženou, ale také na další př́buzenské vztahy a též stabilní stejnopohlavní partnerství.

36 Bod 46. nálezu Ústavního soudu ze dne 14. června 2016, sp. zn. Pl. ÚS 7/15. 
Ustanovení \13 odst. 2 zákona o registrovaném partnerství nepochybně mělo být zrušeno, nebot' znevýhodňovalo homosexuály, kteři se rozhodli svůj vztah institucionalizovat, aniž by tím sledovalo racionální důvody. Reálný dopad rozhodnutí ukáže až budoucnost, nebot' registrovaným partnerům umožnilo ucházet se o individuální osvojení. Př́ípadný úspěch však závisí na posouzení konkrétní situace.

\section{Mezinárodní exkurz - současné evropské trendy}

Problematika osvojení stejnopohlavními páry, či samotnými gayi a lesbami, je mezinárodní a každý stát se s ní musí vypořádat. Považujeme proto za vhodné nastínit také postavení leseb a gayů v ostatních státech Evropské unie, nebot’ představují vhodný referenční rámec.

Z 28 členských států Evropské unie mohou osoby stejného pohlaví uzavřít ve 12 zemích manželství. ${ }^{37} \mathrm{~V}$ dalších 5 státech ${ }^{38}$ mohou uzavř́it registrované partnerství. ${ }^{39}$ Celkově tak 17 států z 28 členských států umožňuje nějakým způsobem institucionalizovat partnerské vztahy gayů a leseb. V této souvislosti je třeba poznamenat, že možnost institucionalizace stejnopohlavních svazků se stala minimálním standardem pro státy Rady Evropy. ${ }^{40}$ Z těchto 17 států připouští společné osvojení i osvojení dítěte partnera 14 států ${ }^{41}$ a pouze osvojení dítěte partnera umožňuje jeden stát. ${ }^{42}$ Ze 17 států Evropské unie, které umožnují institucionalizovat vztah stejnopohlavních párů, zapovídá registrovaným partnerům osvojení, pouze Česká republika a Mad’arsko. ${ }^{43}$ Současný zákaz osvojení registrovanými partnery je proto spíše menšinovým postojem a v nadpoloviční většině států Evropské unie nejsou registrovaní partneři v osvojení omezeni.

37 Jedná se o Belgii, Dánsko, Finsko, Francii, Irsko, Lucembursko, Nizozemí, Portugalsko, Slovinsko, Španělsko, Švédsko a Velkou Británii.

38 Jedná se o Rakousko, Českou republiku, Německo, Mad’arsko, Maltu.

39 Některé další státy, jako např́ílad Francie, nebo Belgie, umožňují gayům a lesbám uzavř́ít jak registrované partnerství, tak manželství.

40 K tomuto závěru dospěl ESLP rozsudku ze dne 21. července 2015, Oliari a ostatní v Itálie, č. stížností. 18766/11 a 36030/11.

41 Kromě států, které neomezují vstup do manželství sexuální orientací, se jedná o Maltu a Rakousko.

42 Jedná se o Německo.

43 Data byla čerpána z materiálu zpracovaného organizací ILGA Europe (Rainbow Map Index 2014 [online] ILGA Europe [cit. 9. 1. 2016] dostupné z: www.ilga-europe.org/rainboweurope) a z aktuálních zpráv o vývoji ve Slovinsku (napry. Slovenia: Law on Same-Sex Marriage and Adoption Rights Passed [online] Library of Congress, 9. 3. 2015 [cit. 9. 1. 2016] dostupné z: http://www.loc.gov/lawweb/servlet/lloc_news?disp3_1205404336_text), Finsku (napry. Finnish Parliament approves same-sex marriage [online] yle uutiset, 28. 11. 2014 [cit. 14. 4. 2015] dostupné z: http://yle.fi/uutiset/finnish_parliament_approves_same-sex_ marriage/7657759), Irsku (např. Children and Family Relationship Bill passed in Seanad [online] RTÉ News, 31. 3. 2015 [cit. 9. 1. 2016] dostupné z: http://www.rte.ie/news/2015/0330/690964-child-and-family-bill/) a Lucembursku (např. Luxembourg legalizes same-sex marriage, adoption [online] Jurist, 19. 6. 2014 [cit. 9. 1. 2016] dostupné z: http://jurist.org/paperchase/2014/06/luxembourg-legalizes-same-sex-marriage-adoption.php). 
Otázkou zákazu osvojení dítěte registrovanými partnery se zabýval také rakouský Ústavní soudní dvůr, který posuzoval ústavnost zákazu společného osvojení registrovanými partnery. ${ }^{44}$ Dospěl přitom k závěru, že taková úprava je protiústavní, nebot’ odporuje zásadě rovného zacházení, protože znevýhodňuje registrované partnery pro jejich sexuální orientaci tím, že jim znemožňuje společně osvojit dítě. Rakouský Ústavní soudní dvůr nenalezl pro takové rozlišování žádné věcné odůvodnění, a proto předmětná ustanovení s účinností ke dni 31. prosince 2015 zrušil. Argumentaci apelující na ochranu nejlepšího zájmu dítěte odmítl jako nevhodnou, nebot' taková argumentace vychází z mylného předpokladu, že sexuální orientace rodičů může být měřítkem kvality rodičovské péče. Jestliže rakouský Ústavní soudní dvůr považoval zákaz společného osvojení za neústavní, tím spíše by považoval za neústavní jakýkoliv zákaz osvojení registrovanými partnery.

\section{Závěr}

Zákaz osvojení registrovanými partnery byl ústavně nekonformní, a proto jej Ústavní soud zrušil. Registrovaní partneři byli znevýhodněni oproti ostatním osobám, aniž by proto existoval racionální důvod. Za odmítáním možnosti osvojení registrovanými partnery se zpravidla skrývá obava z vhodnosti gayů a leseb jako rodičů. Odhlédneme-li od toho, že sexuální orientace nevypovídá o schopnostech vychovávat dítě, odborné studie prokázaly, že tyto děti nejsou nijak znevýhodněny oproti dětem vychovávaným různopohlavními páry. Nejsou znevýhodněny ani oproti dětem o které pečuje pouze jeden rodič.

Nález Ústavního soudu ovšem umožnil toliko osvojení právně volných dětí. Neotevřel cestu k tzv. přiosvojení dítěte partnera. Tato otázka ani nebyla předmětem řízení. Nyní je tak na zákonodárci, aby vyjádřil svưj postoj k této otázce. V současnosti je projednávána poslanecká novela zákona o registrovaném partnerství, která by přiosvojení dítěte partnera umožnila. ${ }^{45}$ Vzhledem $\mathrm{k}$ pomalému postupu projednávání této novely vláda před časem zvažovala podání vlastního návrhu, který by byl přednostně projednán. ${ }^{46}$ Vzhledem k uplynulé době od tohoto prohlášení však lze očekávat, že vládní návrh podán nebude, nebot' ještě nebyl projednán ani samotnou vládou. ${ }^{47}$

44 Nález Ústavního soudního dvora Rakouska ze dne 11. prosince 2014, č. j. G 119-120/201412, dostupný z: http://www.ris.bka.gv.at/Dokumente/Vfgh/JFT_20141211_14G00119_00/ JFT_20141211_14G00119_00.pdf

45 Sněmovní tisk č. 320. Dostupné z: http://www.psp.cz/sqw/text/tiskt.sqw?O=7 \& CT=320 \& CT1=0

46 MinistrJiř́Dienstbiernatiskovékonferenciknovele zákonao registrovanémpartnerství[online] VládaČR, 18.9.2015 [cit. 18.8.2016]Dostupnéz:http://www.vlada.cz/cz/clenove-vlady/pri-uradu-vlady/jiri-dienstbier/aktualne/ ministr-jiri-dienstbier-na-tiskove-konferenci-k-novele-zakona-o-registrovanem-partnerstvi-134811/

47 Náurh zákona, kterým se mèní zákon č. 115/2006 Sb., o registrovaném partnerstvi a o żmènè některých souvisejúcich zákoni, ve znèni pozdèjšich prédpisui, a dalši souvisejici zákony [online] VeKLEP, 11. 3. 2016 [cit. 18. 8. 2016] Dostupné z: https://apps.odok.cz/veklep-detail?pid=KORNA7QCSSE2 
Omezení možnosti osvojit dítě registrovanými partnery znevýhodňuje především samotné děti, které jsou již nyní fakticky vychovávány registrovanými partnery. Zároveň nelze očekávat, že by zrušením tohoto omezení došlo k enormnímu nárůstu dětí vychovávaných registrovanými partnery. Odstraněním zákazu by nebyly pominuty práva dítěte a jeho postavení by se nikterak nezhoršilo. Rozhodnutí o osvojení totiž náleží soudu. Posouzení, zda je v zájmu dítěte, aby bylo osvojeno konkrétními partnery, či partnerem samostatně je předmětem právě soudního řízení. Zrušení zákazu osvojení tak umožnilo registrovaným párům se o osvojení vưbec ucházet. Postavení dětí, které jsou nyní vychovávány registrovanými partnery, se však nemění. Právo by mělo reagovat na společenskou realitu, nebot' jeho schopnost normovat jednání proti přesvědčení lidí, tj. adresátů práva, je značně omezená. V současnosti registrovaní partneři vychovávají stovky dětí. Domníváme se proto, že by partnerům mělo být umožněno společně osvojit cizí dítě a také přiosvojit dítě partnera za srovnatelných podmínek jako manželům. Tato debata by se však měla odehrát spíše na pưdě zákonodárce, nežli ústavního soudnictví, nebot' je úkolem zákonodárce vytvářet zákonný rámec pro život společnosti a umožnit tak vzájemné soužití. ${ }^{48}$

48 Demokratický deficit zákonoberné aktivity Ústavního soudu připomíná také ve svém disentu soudce Vladimír Sládeček. 